\title{
PENERAPAN METODE BERMAIN DALAM MENINGKATKAN KECERDASAN KINESTETIK SISWA PADA PEMBELAJARAN AKUATIK DI SEKOLAH DASAR
}

\author{
Dodong Wiganda \\ SDN Nangela Kecamatan Paseh Kab. Bandung \\ Email: dodongwiganda@yahoo.com
}

Naskah diterima : 17 Februari 2019, direvisi : 5 April 2019, disetujui : 15 April 2019

\begin{abstract}
Abstrak
Tujuan penelitian ini adalah untuk meningkatkan kecerdasan kinestetik siswa dengan menerapkan metode bermain. Metode yang digunakan dalam penelitian ini adalah penelitian tindakan kelas yang terdiri dari tiga siklus dan tiap siklusnya terdiri atas empat tahap yaitu perencanaan, pelaksanaan, observasi dan refleksi, dengan subjek penelitian yaitu siswa di SD Negeri Nangela Kecamatan Paseh Kabupaten Bandung tahun ajaran 2017/2018. Data dikumpulkan melalui tes praktek, observasi, wawancara, pembuatan jurnal catatan guru dan penyebaran angket. Hasil tes kecerdasan kinestetik siswa pada pembelajaran akuatik yang menggunakan metode bermain pada siklus I yaitu; 9,5\% memperoleh kriteria cukup baik (sebanyak 4 siswa), $81 \%$ memperoleh kriteria baik (sebanyak 34 siswa), dan 9,5\% memperoleh kriteria sangat baik (sebanyak 4 siswa). Kecerdasan kinestetik siswa pada pembelajaran akuatik yang menggunakan metode bermain pada siklus II yaitu; 59,5\% memperoleh kriteria baik (sebanyak 25 siswa), dan 40,5\% memperoleh kriteria sangat baik (sebanyak 17 siswa). Serta hasil kecerdasan kinestetik siswa pada pembelajaran akuatik yang menggunakan metode bermain pada siklus III yaitu; $19 \%$ memperoleh kriteria baik (sebanyak 8 siswa), dan $81 \%$ memperoleh kriteria sangat baik (sebanyak 34 siswa). Kesimpulan yang diperoleh dalam penelitian ini yaitu penerapan metode bermain dapat meningkatkan kecerdasan kinestetik siswa pada pembelajaran akuatik di sekolah dasar.
\end{abstract}

Kata Kunci: Metode Bermain, Kecerdasan Kinestetik Siswa

Pengutipan: Dodong Wiganda. (2019). Penerapan Metode Bermain dalam Meningkatkan Kecerdasan Kinestetik Siswa pada Pembelajaran Akuatik di Sekolah Dasar. JMIE: Journal of Madrasah Ibtidaiyah Education,3(1), 2019, 32-40. jmie.v3i1.95.

Permalink/DOI: http://dx.doi.org/ 10.32934/jmie.v3i1.95 


\section{PENDAHULUAN}

Pendidikan jasmani merupakan media untuk mendorong perkembangan keterampilan motorik, kemampuan fisik, pengetahuan dan penalaran, penghayatan nilai-nilai (sikap-mental-emosionalspiritual-sosial), serta pembiasaan pola hidup sehat yang bermuara untuk merangsang pertumbuhan dan perkembangan yang seimbang. Salah satu kajian dalam mata pelajaran jasmani di SD adalah standar kompetensi permainan dan olahraga. Standar kompetensi ini memuat berbagai macam permainan dan cabang olahraga, diantaranya cabang olahraga akuatik.

Usia sekolah dasar kelas rendah merupakan usia yang sangat penting bagi pertumbuhan dan perkembangan anak. Pada masa itu, pertumbuhan dan perkembangan intelegensi serta motorik anak berkembang cepat. Usia sekolah dasar kelas rendah termasuk masa yang tepat untuk memperkenalkan anak pada kegiatan air dan mengajarkan keahlian dasar berenang. Program pembelajaran akuatik pada usia sekolah dasar kelas rendah bertujuan untuk memperkenalkan anak-anak agar memiliki rasa senang terhadap kegiatan akuatik, berani mengenal risiko dalam kegiatan air, dan mengajarkan keahlian dasar berenang.

Untuk mulai memperkenalkan olah-raga renang pada anak-anak, menurut Bompa (2000: 35) idealnya sudah di-mulai antara usia 3-7 tahun, pada usia 10-12 tahun merupakan usia untuk spe-sialisasi, sedangkan usia prestasi puncak berkisar antara 16-18 tahun. Di negara maju program akuatik sekolah dasar kelas rendah lebih terfokus pada pengenalan aspek motorik di air sebagai dasar keterampilan dasar berenang. Anak tidak diajarkan untuk menjadi perenang hebat melainkan untuk tetap survive di air secara independen dan menyenangi aktivitas yang dilakukan.

Keterampilan renang dapat diperoleh lebih siap pada usia 5 tahun. Meskipun beberapa anak bisa menguasainya lebih awal namun anak yang lebih muda dari 4 tahun memerlukan instruksi yang lebih lama untuk mempelajari keterampilan renang dan dibatasi juga oleh kapasitas syaraf dan otot. Secara fisik anak akan berhasil melakukan gerakan renang setelah serabut otot dan syaraf sudah matang. Oleh karena itu, memiliki anak yang memulai pelajaran renang pada usia awal tidak berarti lebih hebat dalam keterampilan renang atau memiliki kualitas renang yang baik dibandingkan yang memulainya pada umur yang lebih tua.

Pada kelas renang, anak-anak akan lebih mudah menguasai keterampilan renang apabila pertumbuhan dan perkembangan tubuh mereka sudah siap, memiliki motivasi, umpan balik yang positif dari guru, dan bila pengalaman renangnya menyenangkan. Jika anak-anak sudah mampu dalam program renang, dalam diri mereka akan tumbuh sikap preventif terhadap risiko tenggelam.

Salah satu kompetensi siswa yang dapat ditingkatkan dalam pembelajarahn akuatik di sekolah dasar adalah kecerdasan kinestetik siswa. Amstrong (2013) berpendapat bahwa kecerdasan kinestetik atau kecerdasan fisik adalah suatu kecerdasan di mana saat menggunakannya seseorang mampu atau terampil menggunakan anggota tubuhnya untuk 
melakukan gerakan seperti berlari, menari, membangun sesuatu, melakukan kegiatan seni dan hasta karya. Kecerdasan fisik sangar memperngaruhi perkembangan motorik anak.

Kecerdasan kinestetik adalah kemampuan menyelaraskan pikiran dengan badan sehingga apa yang dikatakan akan tertuang dalam bentuk gerakan-gerakan badan yang indah, kreatif dan mempunyai makna. Kecerdasan kinestetik atau disebut juga "cerdas jasmaniah" adalah kemampuan untuk menggunakan seluruh bagian tubuh untuk menyelesaikan masalah atau membuat sesuatu. Orang yang memiliki kecerdasan ini biasa memproses informasi melalui perasaan yang dirasakan melalui aspek badaniah atau jasmaniah. Mereka sangat hebat dalam menggerakan otot-otot besar dan kecil dan senang melakukan aktivitas fisik dan berbagai jenis olahraga, termasuk aktivitas berenang atau akuatik.

Dalam pembelajaran akuatik di sekolah dasar kelas rendah, diperlukan suatu metode pembelajaran yang menyenangkan supaya siswa tidak merasa takut akan air. Salah satu metode yang dapat dijadikan alternatif dalam pembelajaran akuatik adalah metode bermaian. Metode bermain merupakan suatu kegiatan pembelajaran yang memberikan kepuasan kepuasan bagi diri sendiri. Melalui bermain anak memperoleh pembatasan dan memahami kehidupan. Bermain merupakan kegiatan yang memberikan kesenangan dan dilaksanakan untuk kegiatan itu sendiri. Dalam bermain lebih ditekankan pada cara melakukan permainan dari pada hasil yang diperoleh.

Purbalingga (2009: 2) mengungkapkan bahwa metode bermain adalah salah satu bentuk dari sebuah pembelajaran jasmani yang dapat diberikan di segala jenjang pendidikan. Hanya saja, porsi dan bentuk pendekatan bermain yang akan diberikan, harus disesuaikan dengan aspek yang ada dalam kurikulum. Selain itu harus dipertimbangkan juga faktor usia, perkembangan fisik, dan jenjang pendidikan yang sedang dijalani oleh mereka. Selain itu, Ismail (2009: 26) juga menuturkan bahwa permainan ada dua pengertian. Pertama, permainan adalah sebuah aktifitas bermain yang murni mencari kesenangan tanpa mencari menang atau kalah. Kedua, permainan diartikan sebagai aktifitas bermain yang dilakukan dalam rangka mencari kesenangan dan kepuasan, namun ditandai pencarian menang-kalah.

\section{METODE PENELITIAN}

Penelitian dilaksanakan pada siswa kelas I SDN Nangela Kecamatan Paseh Kabupaten Bandung Tahun Ajaran 2017-2018 dengan menggunakan metode Penelitian Tindakan Kelas (PTK). PTK dilakukan dengan tujuan memperbaiki pembelajaran di kelas. PTK merupakan suatu penelitian yang mengangkat masalah-masalah aktual yang dihadapi oleh guru di lapangan. Dengan melakukan PTK, guru memiliki peran ganda, yaitu sebagai praktisi dan peneliti. Desain penelitian ini menggunakan desain Kemmis \& Taggart, dirancang untuk dapat menyelesaikan satu pokok bahasan yang dilaksanakan secara berkelanjutan dengan menggunakan 3 siklus. Dalam penelitian ini peneliti menggunakan beberapa siklus, setiap siklus terdiri dari empat tahap, yaitu: (1) Perencanaan; (2) Tindakan; (3) Observasi/Pengaruh; (4) Survei/Refleksi 
(Wiriaatmadja, 2007). Adapun instrumen yang digunakan pada penelitian ini yaitu: tes praktek, lembar observasi, lembar wawancara, lembar jurnal catatan guru, dan angket.

\section{HASIL PENELITIAN DAN PEMBAHASAN}

Pada pelaksanaan tindakan pembelajaran akuatik menggunakan metode bermain. Metode bermain adalah salah satu bentuk dari sebuah pembelajaran jasmani yang dapat diberikan di segala jenjang pendidikan. Hanya saja, porsi dan bentuk pendekatan bermain yang akan diberikan, harus disesuaikan dengan aspek yang ada dalam kurikulum. Selain itu harus dipertimbangkan juga faktor usia, perkembangan fisik, dan jenjang pendidikan yang sedang dijalani oleh mereka. Pendekatan bermain juga merupakan "sebuah pendekatan pembelajaran yang diorientasikan pada permainan, sehingga pembelajaran dikemas dalam situasi permainan". Jadi pembelajaran akuatik pun dapat dilakukan dengan menggunakan pendekatan bermain yang dikemas dalam situasi permainan. Aktivitas siswa dalam pelaksanaan metode bermain yang bertujuan untuk meningkatkan kecerdasan kinestetik siswa dalam dilaksanakan melalui permainan air, seperti lomba lari dengan menggendong, permainan hitam-hijau, permainan kucing air dan ikan, permainan mengambil uang, permainan menghalau racun, permainan motor boat, permaianan buaya bergerak di air, serta permainan sendok dan bola pongpong.

Kegiatan pembelajaran akuatik menggunakan metode bermain dalam meningkatkan kecerdasan kinestetik siswa kelas I SDN Nangela Kecamatan Paseh Kabupaten Bandung dapat dilihat pada gambar berikut:
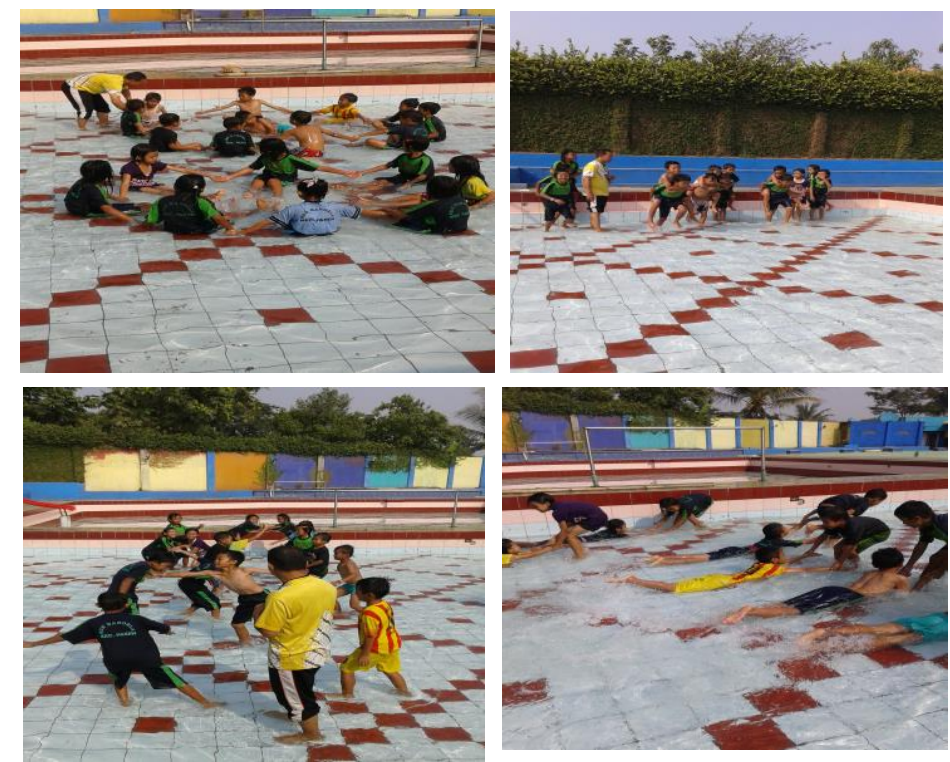

Gambar 1.

\section{Aktivitas Siswa dalam Pembelajaran Akuatik Menggunakan} Metode Bermain 
Berbagai aktivitas siswa yang dilaksanakan pada pembelajaran akuatik menggunakan metode bermain sunggu membuat siswa senang dalam belajar. Siswa nampak antusias dalam mengikuti berbagai permainan dalam pembelajaran akuatik di sekolah dasar. Motivasi siswa dalam belajar menggunakan metode bermain pada pembelajaran akuatik di sekolah dasar juga berdampak pada kecerdasan kinestetik siswa. Hal ini dibuktikan berdasarkan hasil tes kecerdasan kinestetik siswa pada pembelajaran akuatik yang menggunakan metode bermain pada siklus I yaitu; 9,5\% memperoleh kriteria cukup baik (sebanyak 4 siswa), $81 \%$ memperoleh kriteria baik (sebanyak 34 siswa), dan 9,5\% memperoleh kriteria sangat baik (sebanyak 4 siswa). Kecerdasan kinestetik siswa pada pembelajaran akuatik yang menggunakan metode bermain pada siklus II yaitu; 59,5\% memperoleh kriteria baik (sebanyak 25 siswa), dan 40,5\% memperoleh kriteria sangat baik (sebanyak 17 siswa). Serta hasil kecerdasan kinestetik siswa pada pembelajaran akuatik yang menggunakan metode bermain pada siklus III yaitu; $19 \%$ memperoleh kriteria baik (sebanyak 8 siswa), dan $81 \%$ memperoleh kriteria sangat baik (sebanyak 34 siswa).

Peningkatan kecerdasan kinestetik siswa yang menggunakan metode bermain dalam pembelajaran akuatik di sekolah dasar dapat dilihat pada grafik berikut ini:

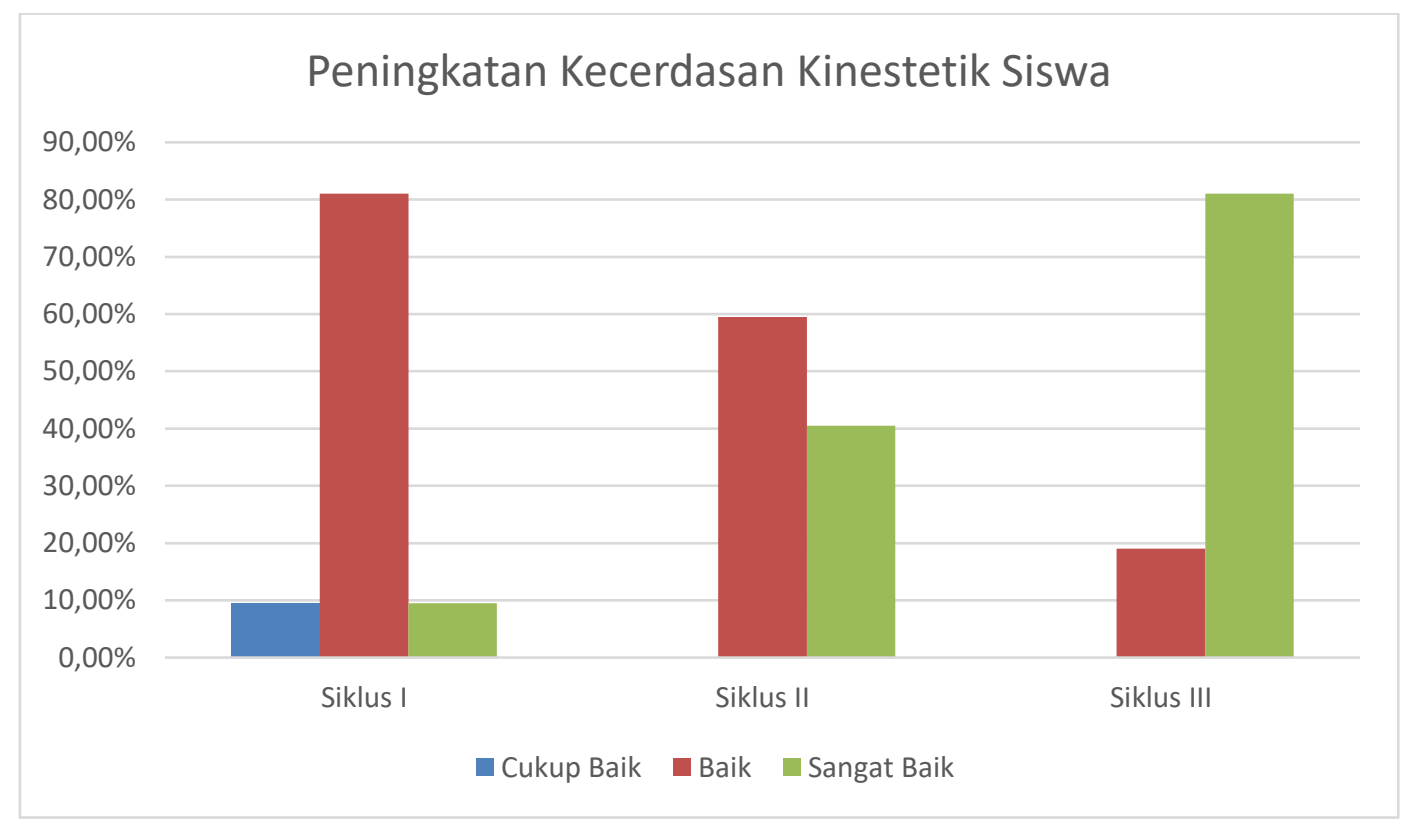

\section{Diagram 1.}

\section{Peningkatan Kecerdasan Kinestetik Siswa Sekolah Dasar pada Pembelajaran Akuatik Menggunakan Metode Bermain}

Berdasakan diagram di atas, dapat diketahui bahwa pembelajaran akuatik menggunakan metode bermain telah memberikan peningkatan yang sangat baik terhadap kecerdasan kinestetik 
siswa sekolah dasar. Terutama pada siklus III, telah terjadinya hasil pembelajaran yang sangat memuaskan, karena 81\% siswa memiliki kecerdasan kinestetik yang sangat baik, dan hanya 19\% yang memiliki kecerdasan kinestetik yang berkategori baik. Selain itu, pembelajaran akuatik yang menggunakan metode bermain membuat siswa termotivasi bekajar, mereka menikmati pembelajaran tanpa bosan dan ingin berhentin. Hal tersebut senada dengan pendapat Domke (Huyen dan Nga, 2003:7) yang menyebutkan bahwa siswa menyukai atmosfer yang santai, unsur kompetitif, dan motivasi yang dibawa oleh permainan dalam kelas. Hal ini karena para siswa memiliki kesempatan untuk menggunakan imaginasi dan kreativitas mereka selama aktifitas seperti permainan didalam kelas; karena itu mereka termotivasi untuk belajar.

Siswa sekolah dasar sebagai pelaku permainan dalam pembelajaran akuatik mengalami dan merasakan manfaat belajar secara langsung tanpa merasakan jenuh yang berlebihan selama di kolam renang. Hal ini dikarenakan siswa merasakan belajar yang menyenangkan di kolam renang yang notabene keluar dari kebiasaan belajar di dalam kelas. Tentu berbeda dengan kegiatan belajar diruang kelas yang lebih menonjolkan aspek kognitif. Meskipun demikian, kegiatan belajar yang efektif adalah dilakukan dengan belajar langsung, dimana siswa bisa merasakan dan mengalami langsung apa yang mereka pelajari. Kegiatan bermain dan belajar berbeda jika ditinjau secara akademis. Keterampilan akademis, seperti berhitung, menulis dan membaca biasa dikuasai dengan proses belajar di kelas. Meskipun demikian bukan berarti aktivitas bermain tidak berperan penting, keterampilan lain yang berhubungan dengan Basic Life Skill, seperti keterampilan berkomunikasi, bersosialisasi, bernegosiasi, dan bekerjasama dalam tim, bisa dipelajari dari proses bermain.

Pembelajaran akuatik yang dilaksanakan dengan metode bermain tentunya merupakan suatu aktivitas yang menyenangkan bagi siswa. Mereka semua bergembira, tertawa dan bahagia mempelajari konsep-konsep yang dibahas dengan menerapkan keterampilan fisik dan kecerdasan kinestetik siswa. Hal ini sejalan dengan pendapat Ahmadi (Novitasari, 2012) yang menjelaskan bahwa metode bermain dilakukan dengan perbuatan yang menyenangkan dan dilakukan atas kehendak sendiri dengan tujuan untuk mendapatkan kesenangan pada waktu melakukan kegiatan tersebut. Selain itu, Arisnawati (Saefudin dkk, 2012) juga mendefinisikan metode permainan adalah cara yang digunakan oleh guru dalam menyajikan pelajaran dengan menciptakan suasana yang menyenangkan, serius tapi santai, dengan tidak mengabaikan tujuan pelajaran yang hendak dicapai. Tentunya dengan penerapan metode bermain, siswa terasa antusias dan bahagia dalam melaksanakan proses belajar mengenai keterampilan-keterampilan berenang di dalam kolam renang.

Metode bermain yang dilakukan di kolam renang yaotu melalui permainan lomba lari dengan menggendong, permainan hitam-hijau, permainan kucing air dan ikan, permainan mengambil uang, permainan menghalau racun, permainan motor boat, permaianan buaya bergerak di air, serta permainan sendok dan bola pongpong. Permainan-permainan tersebut digunakan untuk penciptaan suasana belajar dari pasif ke aktif, dari kaku menjadi gerak (akrab), dan dari jenuh menjadi riang (segar). Metode ini diarahkan agar tujuan belajar dapat dicapai 
secara efisien dan efektif dalam suasana gembira meskipun membahas hal-hal yang sulit atau berat. Sebaiknya permainan digunakan sebagai bagian dari proses belajar, bukan hanya untuk mengisi waktu kosong atau sekedar permainan. Permainan sebaiknya dirancang menjadi suatu 'aksi' atau kejadian yang dialami sendiri oleh peserta, kemudian ditarik dalam proses refleksi untuk menjadi hikmah yang mendalam (prinsip, nilai, atau pelajaran-pelajaran).

Pelaksanaan pembelajaran akuatik yang menggunakan metode bermain di kolam renang cocoknya menggunakan permainan yang kooperatif. Dimana penggolongan kegiatan bermain sesuai dengan dimensi perkembangan anak menurut Gordon (Moeslichatoen, 2004:37) dibagi dalam 4 golongan yaitu: "Bermain secara soliter, bermain secara parallel, bermain secara asosiatif, dan bermain secara kooperatif'. Bermain soliter artinya bermain sendiri tanpa teman. Bermain parallel artinya kegiatan bermain yang dilakukan sekelompok anak dengan menggunakan alat permainan yang sama, tetapi masing-masing anak bermain sendiri. Bermain Asosiatif artinya anak bermain dalam permainan yang sama tapi tidak ada peraturan. Sedangkan bermain kooperatif adalah Masing-masing anak memiliki peran tertentu guna mencapai tujuan bermain. Anak-anak dari kelompok usia akan menunjukan tahapan perkembangan bermain sosial yang berbeda-beda.

Penggolongan kegiatan bermain tersebut diatas dilakukan oleh anak-anak sesuai dengan perkembangan anak secara fitrah. Penggolongan tersebut merupakan tahapan-tahapan perkembangan bermain anak. Anak dapat bermain sendiri dengan bimbingan orang tua atau guru, permainan saling meniru dengan teman, bermain bersama dengan permainan yang mengandung unsur kompetisi. Perkembangan kecerdasan personal anak sangat dirasakan manfaatnya. Dalam proses permainan terdapat unsur aturan-aturan yang harus ditaati, mengerti orang lain, toleransi, kerjasama dan persahabatan. Oleh karena itu, melalui permainan anak dapat dirangsang dan dilatih kecerdasan personalnya karena anak dapat berinteraksi sosial dan berempati.

Pembelajaran akuatik menggunakan metode bermain di sekolah dasar dapat meningkatkan kecerdasan kinestetik. Oleh karena itu, sevaiknya guru melaksankaan pembelajaran bermain yang sesuai dengan karakteristik siswa sekolah dasar. Hal ini sejalan dengan pemdapat Sudono (2006: 20) yang mengemukakan beberapa alasan pemilihan metode bermain dalam pembelajaran yaitu sebagai berikut : (1) Anak-anak membutuhkan pengalaman yang kaya, bermakna, dan menarik, (2) Otak anak senang pada sesuatu yang baru dan hal hal baru yang menantang dan menarik, (3) Rangsangan otak sensori multimedia penting dalam pembelajaran. Makin banyak yang terlibat (visual, audio, dan audio visual) dalam suatu aktivitas, makin besar pula kemungkinan siswa untuk belajar, (4) Anak umumnya senang bergerak, jadi jangan lupa memasukan gerak dalam pembelajaran, (5) Pengulangan adalah kunci belajar. Berikan kegiatan yang membuat siswa dapat mengulang pembelajaran tanpa rasa bosan dan jenuh, (6) Permainan (games) menyenangkan bagi anak. Keinginan untuk belajar dapat meningkat dengan adanya tantangan dan terhabat oleh ancaman yang disertai oleh rasa tidak mampu atau kelelahan. 
Siswa sekolah dasar yang belajar menggunakan metode bermain terbukti mempunyai kecerdasan kinestetik yang sangat baik. Hal ini terbuukti dari hasil penelitian siklus III yaitu 81\% memiliki kecerdasan sangat baik. Adapun ciri-ciri anak yang memiliki kelebihan dalam kecerdasan kinestetik cenderung mempunyai perasaan yang kuat dan kesadaran mendalam tentang gerakan-gerakan fisik. Hal ini dapat terlihat dari aktivitas siswa dalam kegiatan-kegiatan bermain di kolam renang. Mereka mampu berkomunikasi dengan baik melalui bahasa tubuh dan sikap dalam bentuk fisik lainnya. Mereka juga mampu melakukan tugas-tugas aktivitas renang dengan baik setelah melihat orang lain melakukannya terlebih dahulu, kemudian meniru dan mengikuti tindakan-tindakan dalam pembelajaran akuatik di sekolah dasar.

\section{KESIMPULAN}

Hasil tes kecerdasan kinestetik siswa pada pembelajaran akuatik yang menggunakan metode bermain pada siklus I yaitu; 9,5\% memperoleh kriteria cukup baik (sebanyak 4 siswa), $81 \%$ memperoleh kriteria baik (sebanyak 34 siswa), dan 9,5\% memperoleh kriteria sangat baik (sebanyak 4 siswa). Kecerdasan kinestetik siswa pada pembelajaran akuatik yang menggunakan metode bermain pada siklus II yaitu; 59,5 \% memperoleh kriteria baik (sebanyak 25 siswa), dan 40,5 \% memperoleh kriteria sangat baik (sebanyak 17 siswa). Serta hasil kecerdasan kinestetik siswa pada pembelajaran akuatik yang menggunakan metode bermain pada siklus III yaitu; 19 \% memperoleh kriteria baik (sebanyak 8 siswa), dan $81 \%$ memperoleh kriteria sangat baik (sebanyak 34 siswa). Kesimpulan yang diperoleh dalam penelitian ini yaitu penerapan metode bermain dapat meningkatkan kecerdasan kinestetik siswa pada pembelajaran akuatik di sekolah dasar.

\section{DAFTAR PUSTAKA}

Armstrong, Thomas, (2013). Kecerdasan Multiple di Dalam Kelas. Jakarta: PT Indeks.

Huyen, Thanh., and dan Nga, Khuat Thi Thu. (2003). Learning Vocabulary Through Games.

[Online] Tersedia: http://webcache.googleusercontent. com/search?q=cache:GEDzWCaLuqAJ:www.asian-efl-journal.com/dec03v n.pdf $+\& \mathrm{~cd}=2 \& \mathrm{hl}=\mathrm{id} \& \mathrm{ct}=\mathrm{clnk} \quad$ [10 Maret 2018]

Ismail, Adang. (2009). Education Games (Menjadi Cerdas dan Permainan Edukatif). Yogyakarta: Nuansa Aksara.

Moeslichatoen. (2004) MetodePengajaran di tamanKanak-Kanak. Jakarta: RonekaCipta.

Purbalingga, P. (2009). Model Pembelajaran Penjas dengan Bermain. [online]. Tersedia: http://penjaspurbalingga.blogspot.com/2009/12/model-pembelajaran-penjasdengan.html [15 April 2018] 
Saefudin. (2012). Penerapan Metode Permainan Menggunakan Kartu Kosakata Dalam Pembelajaran

Babasa Inggris Siswa Kelas V. [Online] Tersedia:

http://jurnal.fkip.uns.ac.id/index.php/pgsdkebumen/article/view/284/166\Vol 1. No 2 [23 Februari 2018]

Sudono, Anggani (2004) Sumber Belajar dan Alat permainan untuk Anak Usia Dini, Jakarta: Grasindo.

Wiriaatmadja. R. (2007). Metode Penelitian Tindakan Kelas. Bandung : PT Remaja Rosdakarya. 